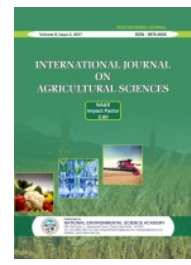

\title{
GROWTH PERFORMANCE OF TISSUE-CULTURED 'LAKATAN' BANANA (MUSA ACUMINATA) PLANTLETS USING STIMULANTS
}

\author{
Alminda Magbalot-Fernandez ${ }^{1}$, John Paul L. Matuguinas ${ }^{1,2}$, Saikat K. Basu ${ }^{3}$ \\ ${ }^{1}$ Rizal Memorial Colleges Inc., Davao City 8000 \\ ${ }^{2}$ Department of Agriculture RFOXI, Agribusiness and Marketing Assistance Division, Davao City \\ ${ }^{3}$ PS Lethbridge, AB Canada T1J 4B3
}

Received: 10.09.2020

Revised: 16.09 .2020

Accepted: 27.09.2020

\begin{abstract}
The study aimed to determine the effects of stimulants on the growth performance of tissue-cultured 'lakatan' banana plantlets (Musa acuminata) under nursery condition; to determine the best treatment combination that will increase the growth performance of tissue-cultured 'lakatan' banana plantlets; and to determine the economic benefits of using stimulants in tissue-cultured 'lakatan' banana plantlets.

The study was laid out in a Complete Randomized Design (CRD) with seven treatments and replicated thrice with eight samples per replicate. The treatments were; T1- Control (No Application); T2- Conventional Practice (CP) (5 grams N-P$\mathrm{K}$ every 15 days); T3- Bio-Forge (5 ml/ liter water foliar application); T4- CP + Bio-Forge (0.125 grams of N-P-K + 5 $\mathrm{ml}$ of Bio-Forge/ liter water); T5- CP + Stimulate (5 grams of N-P-K + $10 \mathrm{ml}$ of Stimulate/ liter water); T6- Bio-Forge + Stimulate ( $5 \mathrm{ml}$ of Bio-Forge/ L. of water $+10 \mathrm{ml}$ of Stimulate/liter water); T7- CP+ Bio-Forge+ Stimulate (5 grams of $\mathrm{N}-\mathrm{P}-\mathrm{K}+5 \mathrm{ml}$ of Bio-Forge/ liter water $+10 \mathrm{ml}$ of Stimulate/ liter water). All data were analyzed through Analysis of Variance (ANOVA) and differences among treatments were computed using Honest Significant (HSD) test.

The results of the study revealed that the percentage of survival and pseudostem diameter at 15 Days after planting (DAP) was not significantly affected by different treatments. Plant height, length of leaves, width of leaves, pseudostem diameter (30 \& 45), number of leaves, root length and number, fresh and dry weights at 15, 30 and 45 DAP have significant effects. The T7 - (Conventional Practice + Bio-Forge + Stimulate) significantly increased plant height by 7 times, width of leaves by 3 times, stem diameter by 6 times, root number by 3 times, fresh weight by 17 times which were comparable with T6- (Bio-Forge + Stimulate), T5- (CP + Stimulate), T4- (CP + Bio-Forge) and T3- (BioForge).

The T3 (Bio-Forge) had the highest leaf length increase by 10 times, root length by $100 \%$ which is comparable to T5(CP + Stimulate), T6- (CP + Stimulate) and T7- (CP + Bio-Forge + Stimulate). While T4- (CP + Bio-Forge) had the heaviest dry weight by 28 times which is also comparable to T3 (Bio-Forge), T5 (CP + Stimulate), T6 (Bio-Forge + Stimulate) and T7- (CP + Bio-Forge + Stimulate).
\end{abstract}

Keywords: Growth Enhancer, Tissue-Cultured, 'Lakatan` Banana, Musa acuminata, Plantlets, Stimulants.

\section{INTRODUCTION}

Banana and Plantains (Musa sp.) are the major staple food for many millions of people throughout the humid and subhumid tropics. The export trade in banana amounts to about seven million tons, indicating that the crop is mainly grown as a food crop for local and export consumption. Banana is an important source of income for small farmers who constitute $75 \%$ of the banana growers among the 80 distinct Philippine banana cultivars, Lakatan, Latundan, Bungulan and Saba, which are popularly grown for the local market. Banana has a great significance; the fruit composed mainly of water as well as carbohydrates, which provides energy in human body. The unripe fruit crop contains more starch and

*Corresponding author: almindafernandez5@gmail.com 
less sugar as compared to the ripe fruits. It contains 11 vitamins; among them are vitamin A, B and C. Nowadays, Lakatan is considered as one of the most important banana cultivars in domestic and export market, moreover, it is the leading fruit crops in terms of volume, area and value of production with the national average yield of 9.4 tons/ha. (http://www.pcarrd.dost.gov.ph).

Edible banana do not form seeds and are propagated vegetatively. In the Philippines, farmers traditionally used sword suckers as planting materials. These planting materials are in great demand during the period when most growers replant their orchards or farm every season to adjust the harvesting period for local market or export. However, one disadvantage of this method is that the disease can be retain in the suckers, causing loss of productivity in the new banana plant. By tissue culture, plants can be free from virus, fungi, bacteria, nematodes and pathogen (Mwinga, 2006). The tissue cultured technique developed by Damasco and Barba (1984) as cited by Sim (2012) was further modified to sustain and become economically viable in vitro propagation system for banana. This technology was developed for the purpose of producing a high and disease-free plants for wide areas. Furthermore the tissue cultured derived plants performed much better in terms of growth, vigor and yield.

Banana plantlets are therefore mass produced through tissue culture. However, growth performance of these plantlets is limited by erratic environmental condition and nutritional constraints in the nursery. Bioforge upregulates key genes associated with stress: DREB1A, Catalase, Dehydrin RAB18, RD29A. It also up-regulates genes controlling root hair growth to enhance nutrient uptake: RLS4 and reduces excess ethylene from stress but leaves ethylene required for normal functioning unaffected. Bio-Forge ${ }^{\circledR}$ enhances seedling emergence. It is a concentrated formulation of Bio-Forge with additional humic acid to ensure early root development and protection from stress on young plants, especially stress associated with cold spring soils or water logged conditions. Bio-Forge ST promotes root nodulation and nodule activity in legumes. Plus, it ensures continuous new root growth for efficient nutrient uptake, especially nitrogen. Overall, Bio-Forge ST improves plant growth hormone balance for continued cellular viability and optimal plant functioning throughout the life of the plant. While Stimulate contains a combination of 3 different phytohormones: cytokinin, gibberellic acid, and indole-3butyric acid necessary to stimulate cell division, cell differentiation and enlargement, nutrient uptake, and nutrient utilization (www.stollerusa.com).
Hence, this study aimed to determine the effects of bioforge and stimulate on the growth performance of tissuecultured 'lakatan' banana plantlets under nursery condition and to determine the best treatment combination that will increase the growth performance of tissue-cultured 'lakatan' banana plantlets.

\section{MATERIALS AND METHODS}

The study was conducted at the research nursery area of the University of Southeastern Philippines, Tagum-Mabini Campus, Mabini Unit, Mampising, Mabini, Compostela Valley Province from the month of November 2014 to January 2015 (Figure 1). The study was laid out in a Complete Randomized Design (CRD) with seven (7) treatments and replicated three (3) times. Each treatment was composed of eight (8) plantlets. Note: $\left(1^{\text {st }}\right.$ Application: 6-25 hrs. after transplant; $2^{\text {nd }}$ application: 7 days after transplant) in both $5 \mathrm{ml}$ Bio-Forge and $10 \mathrm{ml}$ Stimulate).

The treatments were: T1- Control (No Application); T2Conventional Practice (CP) (5 grams N-P-K every 15 days); T3- Bio-Forge (5 ml/ liter water foliar application); T4- CP + Bio-Forge (0.125 grams of N-P-K + $5 \mathrm{ml}$ of BioForge/ liter water); T5- CP + Stimulate (5 grams of N-P-K + $10 \mathrm{ml}$ of Stimulate/ liter water); T6- Bio-Forge + Stimulate (5 ml of Bio-Forge/ L. of water $+10 \mathrm{ml}$ of Stimulate/liter water); $\mathrm{T} 7-\mathrm{CP}+\mathrm{Bio}-\mathrm{Forge}+$ Stimulate (5 grams of N-P-K + $5 \mathrm{ml}$ of Bio-Forge/ liter water $+10 \mathrm{ml}$ of Stimulate/ liter water). All data were analyzed through Analysis of Variance (ANOVA) and differences among treatments were computed using Honest Significant (HSD) test.

A total of 180 plantlets of tissue-cultured 'lakatan' banana plantlets ready for potting from the tissue culture laboratory of USeP-Mabini Campus was used in the study. The tools and equipment used include polyethylene bags (4x6“), shovel, grass hook, bolo, caliper, ruler, ballpen and record book for recording the data. The nursery was prepared by clearing the area and providing a shade of net to condition the plantlets. The potting media were used was coco coir and vermicast. Both were pulverized and properly mixed during bagging operation using the standard ratio of the potting media. The potting medium was composed of $80 \%$ coco coir and $20 \%$ vermicast. This was done by rebagging the plantlets into $4 \times 6$ inches polyethylene bags. One piece of tissue-cultured 'lakatan' banana plantlet was planted per bag and watered immediately. Basal and side-dress application of complete fertilizer was applied based on conventional practice two weeks after planting. The newly transplanted plantlets were protected from direct sunlight by shading them in a nursery net. The shade was gradually 
removed until the plantlets survived in the direct sunlight. Watering was done right after planting and thereafter whenever necessary early in the morning and late in the afternoon to provide enough moisture for growth and development of plantlets. Weeding was maintained from planting to termination. It was done by hand pulling to ensure that the growth of tissue-cultured 'lakatan' banana was not disturbed.

\section{Data Gathered}

The percentage of survival was obtained by counting the number of plants that survived at 15 days from planting. The plant height was determined by measuring 5 sample plants per treatment from the base up to the growing point where the leaves intersect. Measurement was done at 15 days interval using a tape measure/ruler and expressed in centimeters $(\mathrm{cm})$. The increment was computed by subtracting the final height and the initial height. The length of fully developed leaves was determined by measuring 5 representative sample leaves per treatment per replication using ruler at 15 days interval. The increment was computed by subtracting the final length and the initial length. The width of leaves was taken from the same sample leaves which were obtained in length measurement using a ruler at 15 days interval. The increment was computed by subtracting the final width and the initial width. The Pseudostem diameter was determined by measuring 5 representative samples per treatment at 15 days interval using a vernier caliper from the base of the stem. The increment was computed by subtracting the final diameter and the initial diameter. Number of Leaves was determined by counting 5 representative samples per treatment at 15 days. The fully developed leaves were being counted prior to emergence. Root Length was determined by measuring one (1) sample plant per replication per treatments using ruler from the base up to the tip of the primary roots and expressed in centimeters. Number of roots was taken from the same plant per treatment in each replication by counting the number of primary roots per plant on the same one (1) sample upon termination and was expressed by number of quantity. At the time of termination, one (1) fresh sample plant per replication per treatment was taken and weighed at random from each plot.The sample plants taken at random from each plot was oven-dried at $105^{\circ} \mathrm{C}$ for a span of 16 hours to remove completely its moisture content and weighed expressed in grams.

\section{RESULTS AND DISCUSSION}

\section{Percentage of Survival (\%)}

The percent of survival of tissue-cultured 'lakatan' banana plantlets at 15 days after planting (DAP) is presented in Table 1. All tissue-cultured plantlets survived in all treatments. This implies that all the sample tissue-cultured plantlets have high survival capacity. This result coincides with the statement of Abaniza (2008) as cited by Ycot (2005) that tissue-cultured plantlets provide a very high survival after planting which will result in uniform stand.

Table 1: Percentage of survival on tissue-cultured 'lakatan' banana plantlets using stimulants.

\begin{tabular}{|l|c|c|c|c|}
\hline & \multicolumn{3}{|c|}{ REPLICATION } & MEAN \\
\hline TREATMENT & I & II & III & \\
\hline T1- Control ( Untreated ) & 100 & 100 & 100 & 100 \\
\hline T2- Conventional Practice & 100 & 100 & 100 & 100 \\
\hline T3- Bio-Forge & 100 & 100 & 100 & 100 \\
\hline T4- CP + Bio-Forge & 100 & 100 & 100 & 100 \\
\hline T5- CP + Stimulate & 100 & 100 & 100 & 100 \\
\hline T6- Bio-Forge + Stimulate & 100 & 100 & 100 & 100 \\
\hline T7- CP + Bio-Forge + Stimulate & 100 & 100 & 100 & 100 \\
\hline
\end{tabular}

\section{Plant Height Increment (cm)}

Table 2 and Figure 2 presents the Plant height increment of tissue-cultured 'lakatan' banana plantlets using stimulants at 15, 30 and 45 Days after planting (DAP). The result of statistical analysis shows highly significant effects on the 15, 30 and 45 DAP. Based on the result, highest increase in plant height was observed in T7- Conventional Practice +
Bio-Forge + Stimulate which is up to 7 times higher than the T1- Control (Untreated) at 15, 30 and 45 Days after Planting (DAP). T7- Conventional Practice + Bio-Forge + Stimulate has the same effects with T3- Bio-Forge and T4$\mathrm{CP}+$ Bio-Forge, T5- CP + Stimulate and T6 Bio-Forge + Stimulate. 
While lowest increment in height was observed in T1Control (Untreated) and T2- Conventional Practice at 15, 30 and 45 Days After Planting (DAP). Comparable result is also observed between T2- Conventional Practice and T5$\mathrm{CP}+$ Stimulate at $15 \mathrm{DAP}$; among T2- Conventional Practice, T4- CP + Bio-Forge, T5- CP + Stimulate and T6Bio-Forge + Stimulate at 30 DAP; and between T3- BioForge, and T6- Bio-Forge + Stimulate at 45 DAP. This coincides with reports that Bio-Forge tremendously performs well on the growth performance of any crops. A field trial in cotton, soybean and corn conducted by Iowa State University on March 2009 shows that application of Bio-Forge and Stimulate produces better stand growth and root vigor performance in any types of stressors. It contains micronutrients that stimulate the production of auxin, a hormone generated by the plant to trigger vegetative growth.

Table 2: Plant height increment (cm) of tissue-cultured 'lakatan' banana plantlets at 15, 30 and 45 Days after planting (DAP) using stimulants.

\begin{tabular}{|l|c|c|c|}
\hline TREATMENT & 15 DAP** & 30 DAP** & 45 DAP** \\
\hline T1-Control (Untreated) & 0.62c & 0.76c & $0.58 \mathrm{c}$ \\
\hline T2-Conventional Practice & $2.33 \mathrm{~b}$ & $2.84 \mathrm{~b}$ & $1.64 \mathrm{c}$ \\
\hline T3-Bio-Forge & $3.97 \mathrm{a}$ & $4.90 \mathrm{a}$ & $3.44 \mathrm{ab}$ \\
\hline T4-CP + Bio-Forge & $3.95 \mathrm{a}$ & $4.13 \mathrm{ab}$ & $4.15 \mathrm{a}$ \\
\hline T5-CP + Stimulate & $3.55 \mathrm{ab}$ & $4.23 \mathrm{ab}$ & $2.90 \mathrm{~b}$ \\
\hline T6-Bio-Forge + Stimulate & $3.75 \mathrm{a}$ & $4.30 \mathrm{ab}$ & $3.39 \mathrm{ab}$ \\
\hline T7-CP + Bio-Forge + Stimulate & $4.25 \mathrm{a}$ & $4.35 \mathrm{a}$ & $4.26 \mathrm{a}$ \\
\hline C.V. $(\%)=$ & 14.75 & 15.57 & 14.96 \\
\hline
\end{tabular}

$* *=$ Highly Significant

Means in column having common letter are not significantly different at $1 \%$ level of probability using HSD.

This implies that Bio-Forge and Stimulate with application of Conventional Practice ensures greater performance on the growth of the plants. Bio-Forge has the ability to unleash the power of plant on its full grown potential by gearing-up important nutrients needed by the plants. It has a patentented formulation of N,N' — diformyl urea, classified as an antioxidant, and shown to significantly improve growth in a variety of agricultural crops by working on the genetic level. Bio-Forge works by upregulating genes from the plant's own major antioxidative pathways. As Stimulate also enhances cell division, cell differentiation, cell enlargement, root growth and nutrient utilization which resulted to Increase in yield, Improved fruit size and quality and Increased vigor (www.stoller.com).

\section{Length Increment of Leaves (cm)}

As shown in Table 3, the length increment of leaves $(\mathrm{cm})$ of tissue-cultured 'lakatan' banana plantlets was significantly affected by different treatments at 15, 30 and 45 Days After Planting (DAP). Data showed that highest leaf length increase by up to 10 times more was obtained in T3- BioForge treatment at 15, 30, and 45 Days After Planting
(DAP). Similar results were also obtained in T4- CP + BioForge, T5- CP + Stimulate, and T6- Bio-Forge + Stimulate and T7- CP + Bio-Forge + Stimulate. This data coincides with previous results conducted by North Carolina State University in March 2009 on Corn that application of BioForge increases the yield by up-to 20-bushel-per-acre. Application of Bio-Forge alone enhances and promotes length of leaves of tissue-cultured 'lakatan' banana plantlets.

Bio-Forge ${ }^{\circledR}$ has a patented formulation of classified antioxidant (N, N' - diformyl urea), which significantly improves growth in a variety of agricultural crops by working on the genetic level. Bio-Forge works by upregulating genes from the plant's own major antioxidative pathways as well as genes responsible for ethylene production and root growth (www.stollerusa.com).

\section{Width Increment of Leaves (cm)}

Table 4 presents the data on Width Increment of Leaves of tissue-cultured 'lakatan' banana plantlets using stimulants at 15, 30 and 45 DAP. Analysis of Variance showed highly significant differences among treatments. 
Table 3: Length increment of leaves (cm) of tissue-cultured 'lakatan' plantlets at 15, 30, 45 Days after planting (DAP) using stimulants.

\begin{tabular}{|l|c|c|c|}
\hline TREATMENT & 15 DAP** & 30 DAP** & 45 DAP** \\
\hline T1-Control (Untreated) & $0.53^{\mathrm{b}}$ & $0.71^{\mathrm{c}}$ & $1.25^{\mathrm{b}}$ \\
\hline T2-Conventional Practice & $1.72^{\mathrm{bc}}$ & $4.22^{\mathrm{b}}$ & $3.45^{\mathrm{ab}}$ \\
\hline T3-Bio-Forge & $4.94^{\mathrm{a}}$ & $8.32^{\mathrm{a}}$ & $8.67^{\mathrm{a}}$ \\
\hline T4-CP + Bio-Forge & $4.88^{\mathrm{a}}$ & $6.76^{\mathrm{ab}}$ & $7.08^{\mathrm{ab}}$ \\
\hline T5-CP + Stimulate & $4.34^{\mathrm{a}}$ & $6.85^{\mathrm{ab}}$ & $6.26^{\mathrm{ab}}$ \\
\hline T6-Bio-Forge + Stimulate & $3.76^{\mathrm{ab}}$ & $6.25^{\mathrm{ab}}$ & $6.46^{\mathrm{ab}}$ \\
\hline T7-CP + Bio-Forge + Stimulate & $3.17^{\mathrm{ab}}$ & $6.56^{\mathrm{ab}}$ & $6.15^{\mathrm{a}}$ \\
\hline C.V. $(\%)=$ & 24.86 & 20.00 & 36.47 \\
\hline
\end{tabular}

$* *=$ Highly Significant

Means in column having common letter are not significantly different at $1 \%$ level of probability using HSD.

Table 4: Width increment of leaves (cm) of tissue-cultured 'lakatan' banana plantlets at 15, 30 and 45 Days after planting (DAP) using stimulants.

\begin{tabular}{|c|c|c|c|}
\hline TREATMENT & 15 DAP** & 30 DAP** & 45 DAP** \\
\hline T1-Control (Untreated) & $0.90^{\mathrm{b}}$ & $1.03^{\mathrm{c}}$ & $0.31^{\mathrm{b}}$ \\
\hline T2-Conventional Practice & $1.06^{\mathrm{b}}$ & $1.71^{\mathrm{bc}}$ & $1.99^{\mathrm{ab}}$ \\
\hline T3-Bio-Forge & $1.81^{\mathrm{ab}}$ & $4.66^{\mathrm{a}}$ & $2.68^{\mathrm{ab}}$ \\
\hline T4-CP + Bio-Forge & $2.05^{\mathrm{ab}}$ & $3.45^{\mathrm{ab}}$ & $3.38^{\mathrm{ab}}$ \\
\hline T5-CP + Stimulate & $1.79^{\mathrm{ab}}$ & $3.19^{\mathrm{abc}}$ & $3.62^{\mathrm{a}}$ \\
\hline T6-Bio-Forge + Stimulate & $2.16^{\mathrm{ab}}$ & $2.74^{\mathrm{abc}}$ & $5.15^{\mathrm{a}}$ \\
\hline T7-CP + Bio-Forge + Stimulate & $2.81^{\mathrm{a}}$ & $2.96^{\mathrm{abc}}$ & $4.62^{\mathrm{a}}$ \\
\hline C.V. $(\%)=$ & 32.35 & 29.97 & 36.02 \\
\hline
\end{tabular}

*= Significant

$* *=$ Highly Significant

Means in column having common letter are not significantly different at 5\% and 1\% level of probability using HSD.

Result showed that treatment with Bio-Forge and Stimulate increased the width of leaves. Highest width increments at 15 DAP was obtained in T7- CP + Bio-Forge + Stimulate which is not significantly different with T3Bio-Forge, T4- CP + Bio-Forge, and T5- CP + Stimulate T6- Bio-Forge + Stimulate. While T3- Bio-Forge got the highest width increment at 30 DAP similar to T4- CP + BioForge, T5- CP + Stimulate, T6- Bio-Forge + Stimulate and T7- CP + Bio-Forge + Stimulate. Still at 45 DAP, T5- CP + Stimulate, T6- Bio-Forge + Stimulate and T7- CP + BioForge + Stimulate have the highest width increment of leaves as much as 13 times higher which is also the same with T2- Conventional Practice, T3- Bio-Forge and T4- CP + Bio-Forge.

This result supports the study conducted by Ohio State University in March 2009 that application of Bio-Forge on soybean triggers the plants natural hormone (Auxin) which may resulted to visible vegetative growth and yield (www.stoller.com). Combination of Bio-Forge and Stimulate enhances the width size of leaves in tissuecultured 'lakatan' banana plantlets. Bio-Forge has a dreb1A 
master gene for drought tolerance, salt tolerance, frost tolerance, and an increase in expression of genes related to stress tolerance. Physiological studies indicate very good suppression of crop plant ethylene production under abiotic or biotic stress conditions which may provide a healthy and good stand crop.

\section{Pseudostem Diameter Increment (cm)}

As presented in Table 5, the pseudostem diameter increment of tissue-cultured 'lakatan' banana plantlets was significantly affected by stimulants at 15, 30 and 45 Days After Planting.

Table 5: Pseudostem diameter increment (cm) of tissue-cultured 'lakatan' banana plantlets at 15, 30 and 45 Days after planting (DAP) using stimulants.

\begin{tabular}{|c|c|c|c|}
\hline TREATMENT & 15 DAP** & 30 DAP** & 45 DAP** \\
\hline T1-Control (Untreated) & 0.10 & $0.12^{\mathrm{b}}$ & $0.10^{\mathrm{b}}$ \\
\hline T2-Conventional Practice & 0.16 & $0.34^{\mathrm{ab}}$ & $0.10^{\mathrm{b}}$ \\
\hline T3-Bio-Forge & 0.16 & $0.41^{\mathrm{ab}}$ & $0.22^{\mathrm{b}}$ \\
\hline T4-CP + Bio-Forge & 0.26 & $0.36^{\mathrm{ab}}$ & $0.42^{\mathrm{ab}}$ \\
\hline T5-CP + Stimulate & 0.16 & $0.40^{\mathrm{ab}}$ & $0.41^{\mathrm{ab}}$ \\
\hline T6-Bio-Forge + Stimulate & 0.23 & $0.42^{\mathrm{ab}}$ & $0.65^{\mathrm{a}}$ \\
\hline T7-CP + Bio-Forge + Stimulate & 0.23 & $0.48^{\mathrm{a}}$ & $0.74^{\mathrm{a}}$ \\
\hline C.V. $(\%)=$ & 53.90 & 30.21 & 36.98 \\
\hline
\end{tabular}

${ }^{\mathrm{ns}}=$ Not Significant

$*=$ Significant

**= Highly Significant

Means in column having common letter are not significantly different at $1 \%$ and $5 \%$ level of probability using HSD.

Results consistently showed that T7- CP + Bio-Forge + Stimulate increased stem diameter of tissue-cultured 'lakatan' banana plantlets at 30 and 45 Days after Planting (DAP) by up to 6 times higher. At 30 DAP, T7- CP + BioForge + Stimulate is similar in T2- Conventional Practice, T3- Bio-Forge, T4- Conventional Practice + Bio-Forge, T5- CP + Stimulate and T6- Bio-Forge + Stimulate. While at 45 DAP, T7- CP + Bio-Forge + Stimulate was comparable with T4- CP + Bio-Forge, T5- CP + Stimulate and T6 Bio-Forge + Stimulate.

This supports previous results conducted by A\&M University, Texas and Stoller Enterprise Inc. in 2010 that combined application Bio-Forge and Stimulate on cereal crops (wheat and barley) enhances root growth of seedlings, increases crop stem diameter, increases thickness of leaves, enhances crop canopy branching and enhances legume nodule development.

Application of both stoller products (Bio-Forge and Stimulate) or alone will enhances the growth performance of tissue-cultured 'lakatan' banana planlets including Pseudostem diameter. Bio-forge improves nutrient uptake that are essential for the synthesis of hormones, the perception of hormone levels and also impact the length and degree of hormone activity which may resulted to better growth of plants manifested on the leaves, stem, height and yield of the crop (www.stoller.com).

\section{Number of Leaves}

Table 6 and Figure 2 presents the number leaves of tissuecultured 'lakatan' banana plantlets as affected by stimulants at 15, 30 and 45 Days after Planting (DAP). The result of statistical analysis shows highly significant effects at 15 DAP, 30 DAP and 45 DAP.

Results showed that T7- Conventional Practice (CP) + BioForge + Stimulate significantly increased the number of leaves of 'lakatan' banana by $90 \%$ at 15, 30 and 45 Days after Planting (DAP). However, T7 CP + Bio-Forge + Stimulate were comparable with T3 Bio-Forge, T4 CP + Bio-Forge, T5 CP + Stimulate and T6 CP + Bio-Forge and Stimulate at 15 to 45 DAP.

T2 Conventional Practice and T1 Control (no application) also has the same result at 15 and 30 DAP while T2 Conventional practice has higher number of leaves at 45 DAP. This study coincides with the previous reports of Texas A\&M University in 2009 that Bio-Forge and Stimulate enhances growth of seedlings, increases 
thickness of leaves and yields of various crops such as corn and soybean (www.stoller.com).

This indicates that Bio-Forge and Stimulate alone or in combination with conventional practice (CP) will increase the number of leaves of tissue-cultured 'lakatan' banana seedlings. Bio-Forge is a patented formulation of $\mathrm{N}, \mathrm{N}^{\prime}$ - diformyl urea, classified as an antioxidant, and shown to significantly improve growth in a variety of agricultural crops by working on the genetic level while Stimulate contains the 3 growth hormones cytokinin, auxin, and gibberellic acid specifically designed to drive plant growth (www.stollerusa.com).

Table 6: Number of leaves of tissue-cultured 'lakatan' banana plantlets using stimulants at 15, 30 and 45 Days after planting (DAP).

\begin{tabular}{|c|c|c|c|}
\hline TREATMENT & $15 \mathbf{D A P}^{* *}$ & $30 \mathbf{D A P}^{* *}$ & 45 DAP $^{* *}$ \\
\hline T1-Control ( Untreated ) & $2.20^{\mathrm{b}}$ & $2.53^{b}$ & $3.04^{\mathrm{b}}$ \\
\hline T2-Conventional Practice & $2.13^{\mathrm{b}}$ & $3.00^{\mathrm{b}}$ & $4.24^{\mathrm{a}}$ \\
\hline T3-Bio-Forge & $2.40^{\mathrm{ab}}$ & $5.00^{\mathrm{a}}$ & $5.91^{\mathrm{a}}$ \\
\hline T4-CP + Bio-Forge & $2.66^{\mathrm{ab}}$ & $4.60^{\mathrm{a}}$ & $5.83^{\mathrm{a}}$ \\
\hline T5-CP + Stimulate & $2.20^{\mathrm{b}}$ & $4.60^{\mathrm{a}}$ & $5.62^{\mathrm{a}}$ \\
\hline T6-Bio-Forge + Stimulate & $2.66^{\mathrm{ab}}$ & $4.40^{\mathrm{a}}$ & $5.66^{\mathrm{a}}$ \\
\hline T7-CP + Bio-Forge + Stimulate & $3.00^{\mathrm{a}}$ & $4.86^{\mathrm{a}}$ & $5.83^{\mathrm{a}}$ \\
\hline
\end{tabular}

C.V. $(\%)=$

19.59

9.00

6.15

${ }^{* *}=$ Highly Significant

Means in column having common letter are not significantly different at 1\% level of probability using HSD.

Results showed that T7- Conventional Practice (CP) + BioForge + Stimulate significantly increased the number of leaves of 'lakatan' banana by $90 \%$ at 15, 30 and 45 Days after Planting (DAP). However, T7 CP + Bio-Forge + Stimulate were comparable with T3 Bio-Forge, T4 CP + Bio-Forge, T5 CP + Stimulate and T6 CP + Bio-Forge and Stimulate at 15 to 45 DAP.

T2 Conventional Practice and T1 Control (no application) also has the same result at 15 and 30 DAP while T2 Conventional practice has higher number of leaves at 45 DAP. This study coincides with the previous reports of Texas A\&M University in 2009 that Bio-Forge and Stimulate enhances growth of seedlings, increases thickness of leaves and yields of various crops such as corn and soybean (www.stoller.com).

This indicates that Bio-Forge and Stimulate alone or in combination with conventional practice (CP) will increase the number of leaves of tissue-cultured 'lakatan' banana seedlings. Bio-Forge is a patented formulation of $\mathrm{N}, \mathrm{N}^{\prime}-$ diformyl urea, classified as an antioxidant, and shown to significantly improve growth in a variety of agricultural crops by working on the genetic level while Stimulate contains the 3 growth hormones cytokinin, auxin, and gibberellic acid specifically designed to drive plant growth (www.stollerusa.com).

\section{Root Length (cm)}

$\backslash$ Application of Bio-Forge significantly affected the root length of tissue-cultured 'lakatan' banana plantlets as shown in Table 7 and Figure 2.

As presented, the application of T3- Bio-Forge alone significantly had the longest root length of tissue-cultured 'lakatan' banana plantlets which is $100 \%$ longer than the control. This is significantly the same with T5Conventional Practice + Stimulate, T6- Bio-Forge + Stimulate and T7- Conventional Practice + Bio-Forge + Stimulate. Shortest Root lengths were observed in T1Control and T2- Conventional Practice. However, T2 has the same effect with T4- Conventional Practice + BioForge, T5- Conventional Practice + Stimulate, T6- BioForge + Stimulate and T7- Conventional Practice + BioForge + Stimulate

This agrees with the previous results that Bio-Forge improved the growth performance of root in various crops 
such as corn and soybean. In 2010 AgriServe Company conducted a field testing study on Corn at Russellville, USA and found out that during vegetative stage a more healthy plant, larger leaves and larger root length which resulted to positive yield results from an average of 3.57 bushels increase in double crop and 1.59 bushel in full season (www.stoller.com).

This implies that Bio-Forge alone increases root length of tissue-cultured 'lakatan' banana plantlets. Bio-Forge enhances seedling emergence with concentrated formulation of additional humic acid to ensure early root development and protection from stress on young plants, especially stress associated with cold spring soils or water logged conditions. Bio-Forge also promotes root nodulation and nodule activity in legumes. Plus, it ensures continuous new root growth for efficient nutrient uptake, especially nitrogen. Overall, Bio-Forge improves plant growth hormone balance for continued cellular viability and optimal plant functioning throughout the life of the plant (www.stoller.com).

\section{Number of Roots}

Bio-Forge and Stimulate significantly affected the number of roots of tissue-cultured 'lakatan' banana plantlets as shown in Table 8 and Figure 2.

Table 7: Root length (cm) of tissue-cultured 'lakatan' banana plantlets using stimulants.

\begin{tabular}{|l|c|c|}
\hline TREATMENT & & $\begin{array}{c}\text { MEAN } \\
\text { Root Length** }\end{array}$ \\
\hline T1- Control (Untreated) & & $17.00^{\mathrm{c}}$ \\
\hline T2- Conventional Practice & & $20.33^{\mathrm{bc}}$ \\
\hline T3- Bio-Forge & & $35.83^{\mathrm{a}}$ \\
\hline T4- CP + Bio-Forge & & $21.33^{\mathrm{bc}}$ \\
\hline T5- CP + Stimulate & & $25.00^{\mathrm{abc}}$ \\
\hline T6- Bio-Forge + Stimulate & & $25.83^{\mathrm{abc}}$ \\
\hline T7- CP + Bio-Forge + Stimulate & & $31.16^{\mathrm{ab}}$ \\
\hline C.V. (\%) & & 17.50 \\
\hline
\end{tabular}

${ }^{* *}=$ Highly Significant

Means in column having common letter are not significantly different at $1 \%$ level of probability using HSD.

Table 8: Number of roots on tissue-cultured 'lakatan' banana plantlets using stimulants.

\begin{tabular}{|l|c|}
\hline TREATMENT & $\begin{array}{r}\text { MEAN } \\
\text { Number } \text { Roots** }^{* *}\end{array}$ \\
\hline T1-Control (Untreated) & $4.33^{\mathrm{c}}$ \\
\hline T2-Conventional Practice & $9.33^{\mathrm{b}}$ \\
\hline T3-Bio-Forge & $10.66^{\mathrm{ab}}$ \\
\hline T4-CP + Bio-Forge & $10.66^{\mathrm{ab}}$ \\
\hline T5-CP + Stimulate & $10.33^{\mathrm{b}}$ \\
\hline T6-Bio-Forge + Stimulate & $10.00^{\mathrm{b}}$ \\
\hline T7-CP + Bio-Forge + Stimulate & $13.00^{\mathrm{a}}$ \\
\hline
\end{tabular}

C.V. $(\%)=8.56$

**= Highly Significant

Means in column having common letter are not significantly different at $1 \%$ level of probability using HSD. 
Result shows that T7- CP + Bio-Forge + Stimulate increased up to 3 times greater number of root of tissuecultured 'lakatan' banana plantlets, which is significantly the same with T3- Bio-Forge and T4- CP + Bio-Forge. This is followed by T5- CP + Stimulate and T6 Bio-Forge + Stimulate which have comparable effects with T2Conventional Practice, T3- Bio-Forge, T4- CP + BioForge, T5- CP + Stimulate and T6- Bio-Forge + Stimulate. Fewer number of roots lengths were greatly observed in T1- Control and T2- Conventional Practice.

This again conforms with the previous results conducted in 2010 by AgriServe Company in Murray, USA on Soybean that Bio-Forge and Stimulate application significantly produces healthy and vigor plants especially on the root aspects which resulted to positive yield response with this application timing (www.stoller.com).

Combination of the two products (Bio-Forge or Stimulate) or alone will precisely increased the number of root of Tissue-cultured 'lakatan' banana plantlets.

Bio-Forge also promotes optimal plant root growth by regulating up- specific key genes associated with stress factor that ensures continuous new root growth for efficient nutrient uptake, especially nitrogen, while Stimulate contains a combination of 3 important phytohormones that are necessary in cell division, cell differentiation, and cell arrangement in all positions of the plant in order to maximize cell division. It is the number of cells that a plant can synthesize which will determine the plant size. The more cells that the plant synthesizes the more it will produce better root formation (www.stollerusa.com).

\section{Fresh Weight (grams)}

Fresh weight of tissue-cultured 'lakatan' banana plantlets was significantly affected by the different treatments as shown in Table 9. As shown, T7- CP + Bio-Forge + Stimulate, T3- Bio-Forge and T4 CP + Bio-Forge and T6 Bio-Forge + Stimulate got up to 17 times more fresh weight in tissue-cultured 'lakatan' banana plantlets, which is comparable to T5- CP + Stimulate. The lowest fresh weight in tissue-cultured 'lakatan' banana plantlets were observed in T1- Control followed by T2- Conventional Practice, which has the same effect with T5- CP + Stimulate.

Table 7: Root length (cm) of tissue-cultured 'lakatan' banana plantlets using stimulants.

\begin{tabular}{|l|c|c|}
\hline TREATMENT & & $\begin{array}{c}\text { MEAN } \\
\text { Root Length** }\end{array}$ \\
\hline T1- Control (Untreated) & & $17.00^{\mathrm{c}}$ \\
\hline T2- Conventional Practice & & $20.33^{\mathrm{bc}}$ \\
\hline T3- Bio-Forge & & $35.83^{\mathrm{a}}$ \\
\hline T4- CP + Bio-Forge & & $21.33^{\mathrm{bc}}$ \\
\hline T5- CP + Stimulate & & $25.00^{\mathrm{abc}}$ \\
\hline T6- Bio-Forge + Stimulate & & $25.83^{\mathrm{abc}}$ \\
\hline T7- CP + Bio-Forge + Stimulate & & $31.16^{\mathrm{ab}}$ \\
\hline C.V. $\%)=$ & & 17.50 \\
\hline
\end{tabular}

${ }^{* *}=$ Highly Significant

Means in column having common letter are not significantly different at $1 \%$ level of probability using HSD.

As presented, the application of T3- Bio-Forge alone significantly had the longest root length of tissue-cultured 'lakatan' banana plantlets which is $100 \%$ longer than the control. This is significantly the same with T5Conventional Practice + Stimulate, T6- Bio-Forge + Stimulate and T7- Conventional Practice + Bio-Forge + Stimulate. Shortest Root lengths were observed in T1Control and T2- Conventional Practice. However, T2 has the same effect with T4- Conventional Practice + Bio-
Forge, T5- Conventional Practice + Stimulate, T6- BioForge + Stimulate and T7- Conventional Practice + BioForge + Stimulate .

This agrees with the previous results that Bio-Forge improved the growth performance of root in various crops such as corn and soybean. In 2010 AgriServe Company conducted a field testing study on Corn at Russellville, USA and found out that during vegetative stage a more 
healthy plant, larger leaves and larger root length which resulted to positive yield results from an average of 3.57 bushels increase in double crop and 1.59 bushel in full season (www.stoller.com).

This implies that Bio-Forge alone increases root length of tissue-cultured 'lakatan' banana plantlets. Bio-Forge enhances seedling emergence with concentrated formulation of additional humic acid to ensure early root development and protection from stress on young plants, especially stress associated with cold spring soils or water logged conditions. Bio-Forge also promotes root nodulation and nodule activity in legumes. Plus, it ensures continuous new root growth for efficient nutrient uptake, especially nitrogen. Overall, Bio-Forge improves plant growth hormone balance for continued cellular viability and optimal plant functioning throughout the life of the plant (www.stoller.com).

\section{Number of Roots}

Bio-Forge and Stimulate significantly affected the number of roots of tissue-cultured 'lakatan' banana plantlets as shown in Table 8 and Figure 2.

Table 8: Number of roots on tissue-cultured 'lakatan' banana plantlets using stimulants.

\begin{tabular}{|l|c|}
\hline TREATMENT & $\begin{array}{c}\text { MEAN } \\
\text { Number of Roots** }\end{array}$ \\
\hline T1-Control ( Untreated ) & $4.33^{\mathrm{c}}$ \\
\hline T2-Conventional Practice & $9.33^{\mathrm{b}}$ \\
\hline T3-Bio-Forge & $10.66^{\mathrm{ab}}$ \\
\hline T4-CP + Bio-Forge & $10.66^{\mathrm{ab}}$ \\
\hline T5-CP + Stimulate & $10.33^{\mathrm{b}}$ \\
\hline T6-Bio-Forge + Stimulate & $10.00^{\mathrm{b}}$ \\
\hline T7-CP + Bio-Forge + Stimulate & $13.00^{\mathrm{a}}$ \\
\hline C.V. $\%$ ) $=$ & 8.56 \\
$* *=$ Highly Significant & \\
Means in column having common letter are not significantly different at 1\% level of probability using HSD.
\end{tabular}

Result shows that T7- CP + Bio-Forge + Stimulate increased up to 3 times greater number of root of tissuecultured 'lakatan' banana plantlets, which is significantly the same with T3- Bio-Forge and T4- CP + Bio-Forge. This is followed by T5- CP + Stimulate and T6 Bio-Forge + Stimulate which have comparable effects with T2Conventional Practice, T3- Bio-Forge, T4- CP + BioForge, T5- CP + Stimulate and T6- Bio-Forge + Stimulate. Fewer number of roots lengths were greatly observed in T1- Control and T2- Conventional Practice.

This again conforms with the previous results conducted in 2010 by AgriServe Company in Murray, USA on Soybean that Bio-Forge and Stimulate application significantly produces healthy and vigor plants especially on the root aspects which resulted to positive yield response with this application timing (www.stoller.com).

Combination of the two products (Bio-Forge or Stimulate) or alone will precisely increased the number of root of Tissue-cultured 'lakatan' banana plantlets.
Bio-Forge also promotes optimal plant root growth by regulating up- specific key genes associated with stress factor that ensures continuous new root growth for efficient nutrient uptake, especially nitrogen, while Stimulate contains a combination of 3 important phytohormones that are necessary in cell division, cell differentiation, and cell arrangement in all positions of the plant in order to maximize cell division. It is the number of cells that a plant can synthesize which will determine the plant size. The more cells that the plant synthesizes the more it will produce better root formation (www.stollerusa.com).

\section{Fresh Weight (grams)}

Fresh weight of tissue-cultured 'lakatan' banana plantlets was significantly affected by the different treatments as shown in Table 9. As shown, T7- CP + Bio-Forge + Stimulate, T3- Bio-Forge and T4 CP + Bio-Forge and T6 Bio-Forge + Stimulate got up to 17 times more fresh weight in tissue-cultured 'lakatan' banana plantlets, which is comparable to T5- CP + Stimulate. The lowest fresh weight in tissue-cultured 'lakatan' banana plantlets were observed 
in T1- Control followed by T2- Conventional Practice,

which has the same effect with T5- CP + Stimulate.

Table 9: Fresh weight (grams) of tissue-cultured 'lakatan' banana plantlets using stimulants.

\begin{tabular}{|l|c|}
\hline TREATMENT & $\begin{array}{c}\text { MEAN } \\
\text { Weight (g)** }\end{array}$ \\
\hline T1-Control (Untreated) & $3.03 \mathrm{c}$ \\
\hline T2-Conventional Practice & $19.66 \mathrm{bc}$ \\
\hline T3-Bio-Forge & $50.43 \mathrm{a}$ \\
\hline T4- CP + Bio-Forge & $49.46 \mathrm{a}$ \\
\hline T5- CP + Stimulate & $37.10 \mathrm{ab}$ \\
\hline T6- Bio-Forge + Stimulate & $31.66 \mathrm{a}$ \\
\hline T7- CP + Bio-Forge + Stimulate & $53.86 \mathrm{a}$ \\
\hline
\end{tabular}

C.V. $(\%)=23.20$

**= Highly Significant

Means in column having common letter are not significantly different at 1\% level of probability using HSD.

Explanation can be pointed out by the report conducted by A\&M University at Texas. Results from 3 experiments indicated that soil treatment with water containing $0.6 \%$ Bioforge previous to the drought treatment increased survival of water-deprived plants by an average of $44 \%$ this indicates that treatment applied with Bio-Forge improved water retention of the plant and resulted to bulk accumulation of water that tends to produced heavier weight of the plants (www.stoller.com).

Combined application of the two product (Bio-Forge or Stimulate) or alone will provide heavier weight on the tissue-cultured 'lakatan' banana plantlets. Bio-Forge is shown to up-regulate the four enzymes that protect plants from damaging free radicals which can occur in response to drought, injury from herbicides and pesticides, nutrient deficiencies and extreme temperatures. The four enzymes are: Mnsuperoxide dismutase Catalase (CAT3), Dehydroascorbate reductase (DHR), Thioredoxin reductase (THR). While Stimulate is a bio-stimulant enhancer uses as a supplement to foliar nutrients. Stimulate enhances cell division, cell differentiation, cell enlargement, root growth and nutrient utilization in which plants make its full grown potential in obtaining more controlled and productive growth.

\section{Dry Weight (grams)}

There were significant differences on the Dry weight of tissue-cultured 'lakatan' banana plantlets as shown in Table 10. Data showed that T4- Conventional Practice + BioForge greatly increased the dry weight of tissue-cultured 'lakatan' banana plantlets by up to 28 times higher than the T1- Control (untreated). T4- Conventional Practice + BioForge is comparable to T3- Bio-Forge, T5- CP + Stimulate, T6- Bio-Forge + Stimulate and T7- CP + Bio-Forge + Stimulate. Lowest dry weights were observed in T1Control and T2- Conventional Practice which were also statistically the same with T5- CP + Stimulate and T6- BioForge + Stimulate. This indicates that Bio-Forge is effective on carbon absorption which enhances fast performance on the growth of plants. Application of BioForge in combination with Conventional practice will effectively triggers carbon absorption and nitrogen fixation.

Bio-Forge is a stress reducing hormone that provides proper absorption of important nutrient during the development stage of the plants. Dreb1A gene, a gene shown to play a role in drought tolerance. By inducing the regulatory master gene Dreb1A, a cascade affect in turn upregulates other genes involved in resistance to drought and other environmental stresses (www.stoller.com).

\section{Conclusion}

The results of the study revealed that T7- (Conventional Practice + Bio-Forge + Stimulate) significantly increased plant height by 7 times, width of leaves by 3 times, stem diameter by 6 times, root number by 3 times, fresh weight by 17 times which were comparable with T6- (Bio-Forge + Stimulate), T5- (CP + Stimulate), T4- (CP + Bio-Forge) and T3-(Bio-Forge). T3 (Bio-Forge) had the highest leaf length increase by 10 times, root length by $100 \%$ which is comparable to T5- (CP + Stimulate), T6- (CP + Stimulate) 
Table 10: Dry weight (grams) of tissue-cultured 'lakatan' banana plantlets using stimulants.

\begin{tabular}{|l|c|}
\hline TREATMENT & $\begin{array}{c}\text { MEAN } \\
\text { Dry Weight (g)** }\end{array}$ \\
\hline T1-Control (Untreated) & $3.03^{\mathrm{c}}$ \\
\hline T2-Conventional Practice & $19.66^{\mathrm{bc}}$ \\
\hline T3-Bio-Forge & $50.43^{\mathrm{a}}$ \\
\hline T4-CP + Bio-Forge & $49.46^{\mathrm{a}}$ \\
\hline T5-CP + Stimulate & $37.10^{\mathrm{ab}}$ \\
\hline T6-Bio-Forge + Stimulate & $31.66^{\mathrm{a}}$ \\
\hline T7-CP + Bio-Forge + Stimulate & $53.86^{\mathrm{a}}$ \\
\hline
\end{tabular}

C.V. $(\%)=23.20$

**= Highly Significant

Means in column having common letter are not significantly different at $1 \%$ level of probability using HSD.

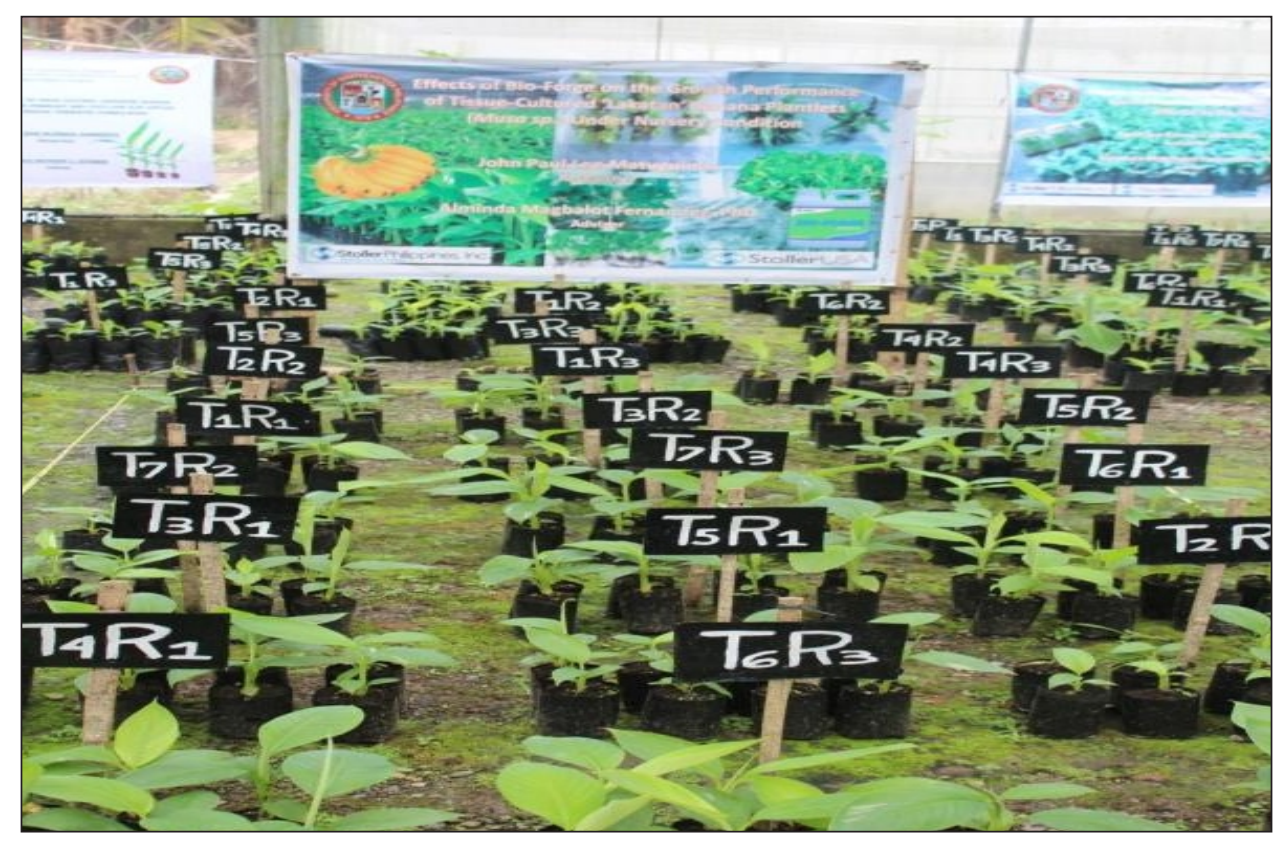

Figure 1: The experimental area at USEP, Mabini, ComVal Province.

and T7- (CP + Bio-Forge + Stimulate). While T4- (CP + Bio-Forge) had the heaviest dry weight by 28 times which is also comparable to T3 (Bio-Forge), T5 (CP + Stimulate), T6 (Bio-Forge + Stimulate) and T7- (CP + Bio-Forge + Stimulate).

Hence, the addition of foliar supplements like bioforge and stimulate with basal fertilizer application resulted to optimum growth of 'lakatan' banana plantlets.

\section{REFERENCES}

1. Ameda, S.M. (2011). Effect of Fermented Plant Juice (FPJ) using Different Plant Residues on the growth of Lakatan Tissue-Cultured Banana Seedlings. Unpublished BSA Undergraduate Thesis. USEPMabini, Compostela ValleyProvince.

2. Fernando, G.B. 2013. Growth Performance of Tissue-Cultured 'Lakatan' Banana using Different Kinds of Growing Media. Unpublished BA Thesis 


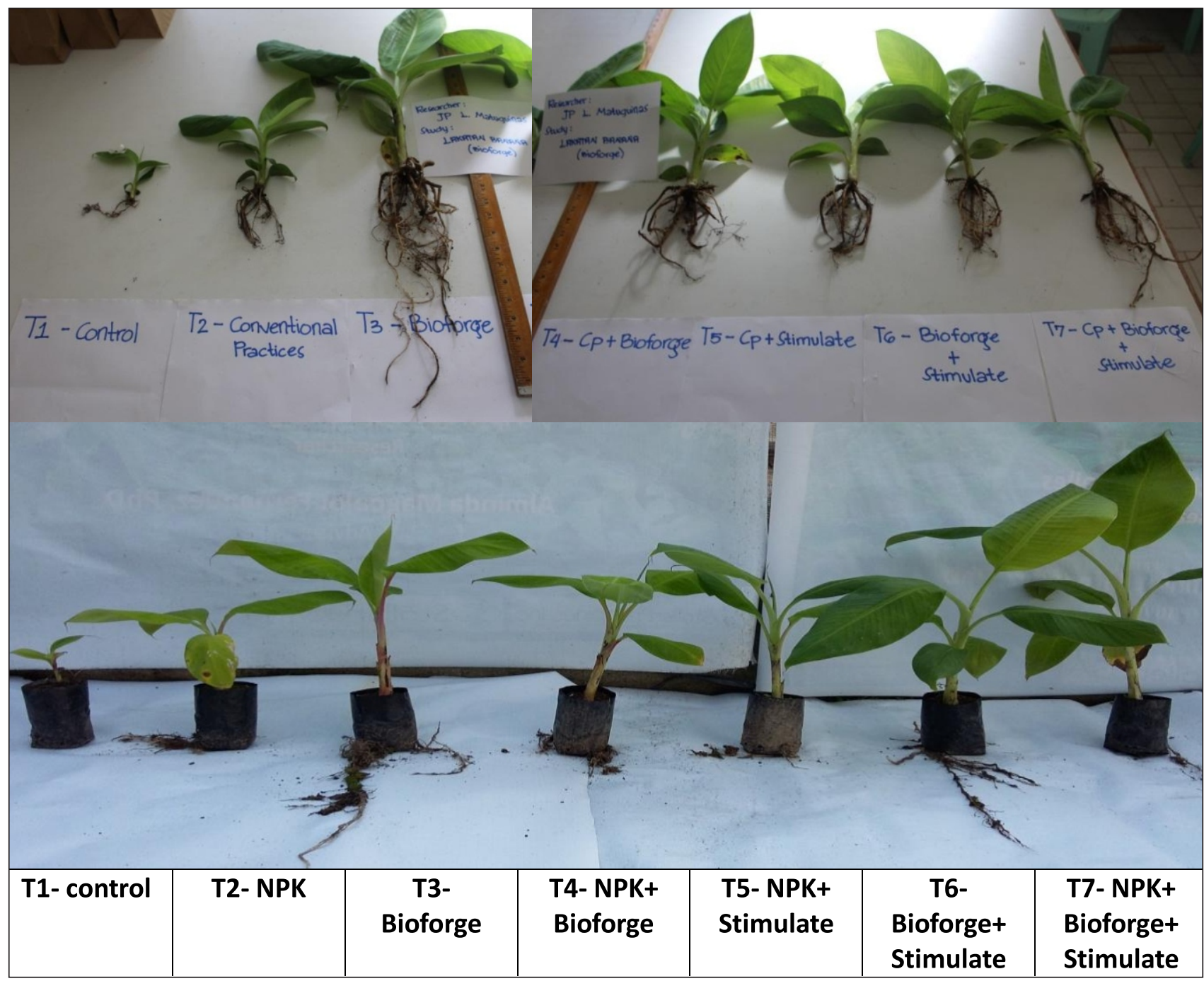

Figure 1: The experimental area at USEP, Mabini, ComVal Province.

USeP-Mabini Campus, Mampising Compostela Valley Province.

3. Gasulla, F. Jr. (2010). Growth Performance of Tissueculture Lakatan Banana Plantlets as Affected by Combination of Coco Coirdust and Vermicast Medium. Unpublished BSA Undergraduate Thesis. USEP-Mabini, Compostela Valley Province.

4. http://www.pcarrd.dost.gov.ph

5. Hwang, Shein Chuan and Hong Jime. (2000). Food and Fertilizer Technology Center Newsletter. p. 7

6. PACOL, D.V. (2011). Growth Performance of tissuecultured 'Cavendish' Banana plantlets in Different
Potting Media. Unpublished BSA Undergraduate thesis.

7. PCARRD, DOST. (2006). Banana Production Manual. Book Series no. 175.a/2006

8. PCARRD. (1992). the Philippines Recommends for Banana.p. 3.

9. PCARRD-DOST, LBL. (2004). Banana Production Manual.p. 42.

10. USEP Banana Tissue Culture Laboratory Manual, 2010

11. www.stollerusa.com 